Working Paper 9513

\title{
A NOTE ON ABSOLUTE PRIORITY RULE VIOLATIONS, CREDIT RATIONING, AND EFFICIENCY
}

by Stanley D. Longhofer

Stanley D. Longhofer is an economist at the Federal Reserve Bank of Cleveland. The author is grateful to Charles Calomiris, Joseph Haubrich, Charles Kahn, James Thomson, and Anne Villamil for helpful comments.

Working Papers of the Federal Reserve Bank of Cleveland are preliminary materials circulated to stimulate discussion and critical comment. The views stated herein are those of the author and not necessarily those of the Federal Reserve Bank of Cleveland or of the Board of Governors of the Federal Reserve System.

November 1995 


\begin{abstract}
Violations of the absolute priority rule (APR) are commonplace in private workouts, formal business reorganizations, and personal bankruptcies. While some theorists suggest that these might arise endogenously, they are clearly magnified by the institutional structure of the bankruptcy code. This paper shows that APR violations exacerbate credit rationing problems by reducing the payment lenders receive in default states. Furthermore, APR violations make default more likely, raising the interest rate that firms must pay when borrowing. Both of these problems arise even when APR violations have no impact on the borrower's incentive to undertake risk-shifting behavior.
\end{abstract}


clevelandfed.org/research/workpaper/1995/wp9513.pdf 


\section{Introduction}

The absolute priority rule (APR) is the theoretical standard by which financial contracts are resolved when a debtor is unable to repay all of his creditors. Simply stated, this rule requires that the debtor receive no value from his assets until all of his creditors have been repaid in full. ${ }^{1}$ While this rule would seem quite simple to implement, it is routinely circumvented in practice.

Violations of the APR in Chapter 11 reorganizations are well documented. Studies by Betker (1995), Franks and Torous (1991), and LoPucki and Whitford (1990) have shown that stockholders of publicly traded companies that have gone through reorganizations receive value about 75 percent of the time, even though their creditors are not paid the full value of their claims. The magnitude of these deviations is not small. Eberhart, Moore, and Roenfeldt (1990) find that the firm's original equityholders retain 7.6 percent of the firm's value on average. ${ }^{2}$ APR violations are not limited solely to corporate bankruptcies. Chapter 5 of the Bankruptcy Code allows individual debtors generous exemptions to protect personal property from their creditors. ${ }^{3}$ In addition, bankruptcy eliminates most claims on a debtor's future wage income, thereby limiting creditors' access to what is typically his most valuable asset: his human capital.

Clearly, the Bankruptcy Code provides implicit support for these violations in some cases and explicit statutory authority for them in others. But whether or not they are beneficial remains

\footnotetext{
${ }^{1}$ The APR also states that more senior creditors should be paid before junior creditors. In this paper, we consider only APR violations between the borrower and a (single) lender.

${ }^{2}$ Betker (1995) and Franks and Torous (1994) find these deviations to be somewhat smaller -2.86 percent and 2.3 percent, respectively.

${ }^{3} 11$ U.S.C. §522.
} 
an open question. A growing body of research suggests that these deviations do, in fact, have negative consequences. Indeed, many recent proposals for amending current bankruptcy law are motivated by the belief that the frequent APR violations inherent in the current system are undesirable. ${ }^{4}$ But this view that the APR should be sacrosanct is by no means universal.

We contribute to this discussion by showing that APR violations make credit rationing problems more severe, since they make lenders less able to offer loans to high-risk borrowers. Furthermore, APR violations make default more likely, increasing the interest rate borrowers must pay when raising funds. Both of these problems arise even when APR violations have no impact on the borrower's incentive to undertake risk-shifting behavior.

The traditional model of credit rationing was developed by Stiglitz and Weiss (1981) and focused on borrowers' adverse selection and moral hazard problems. ${ }^{5}$ Williamson $(1986,1987)$ showed that credit rationing could exist even without these problems, relying instead on the costly state verification framework used in this article. Each of these models of credit rationing focuses on a market made up of many borrowers; in this world, credit rationing means that some borrowers are denied loans even though they are indistinguishable from those who do receive loans.

Since we use a costly state verification environment, our model most closely resembles that of Williamson (1987). Credit rationing occurs in Williamson's model because lenders have different reservation returns, giving him an upward-sloping supply function for loans. In our model, however, there is only one borrower. One advantage to this approach is that it shows the

${ }^{4}$ See Roe (1983), Bebchuk (1988), and Aghion, Hart, and Moore (1992).

${ }^{5}$ See also Gale (1990) and Calomiris and Hubbard (1990). 
essential similarity between a borrower who is credit rationed and one who is "credit constrained." A credit-constrained borrower is one who cannot obtain as large a loan as he might in a perfect capital market with no informational asymmetries. For example, a consumer might be forced to buy a smaller house or a less expensive car, or a business owner might be unable to finance as much inventory as he would like to (and be able to if APR violations did not occur). It should be clear, however, that if we were to posit Williamson's structure for the supply side of the loan market, the credit rationing in our model would be identical to that which he develops.

The next section briefly reviews recent research on the impact of APR violations on financial contracts. Then, in section 3 , we analyze APR violations in a simple costly state verification model. We show that these violations cause the borrower to have a lower expected return ex ante because they increase the probability of default. In section 4 , we show that credit rationing problems are more severe when APR violations are greater; that is, some loans that might be made when APR violations do not occur in default states will not be made when they do. We conclude in section 5 .

\section{Other Views on the APR}

Bulow and Shoven (1978) and White $(1980,1983)$ were among the first to question the efficiency of APRs. ${ }^{6}$ They show that when a firm is in financial distress, the APR generally leads to inefficient investment and liquidation-continuation decisions. In particular, the APR leads to an underinvestment problem, because equityholders can renegotiate their bank debt but

\footnotetext{
${ }^{6}$ See also the later extensions by Gertner and Scharfstein (1991).
} 
not their public bonds. Since the benefits of some positive net present value projects will accrue only to bondholders, the firm has no incentive to undertake them. Berkovitch and Israel (1991) examine the over- and under-investment problems resulting from financial distress in more detail, and show that APR violations allow the firm to renegotiate its debt efficiently, thereby eliminating any perverse investment incentives. Eberhart and Senbet (1993) argue that APR violations act to reduce the risk-shifting incentives of a firm in financial distress: Since shareholders receive a portion of the firm's revenues even in default, they have less incentive to take risky actions that might reduce this value. Together, these papers suggest that APR violations increase efficiency, ex post.

But while these papers might explain why the firm's equityholders and creditors might find APR violations attractive once the firm is in financial distress, they ignore their impact on ex ante efficiency, i.e., the firm's expected profits at the time of the initial financial contracting. Here, opinions are more divided. Bebchuk (1991) focuses on the risk-shifting problem at this initial stage. Since APR violations allow shareholders to receive some value even when the firm is in default, they have an increased incentive to undertake negative net present value projects that entail high risk. Eberhart and Sweeney (1994) find that between 30 and 85 percent of the noise in the market for bankrupt firms' bonds may be attributable to APR violations, and thus conclude that APR violations are detrimental because they add greater uncertainty to the security valuation process. Finally, Rajan and Winton (1994) argue that a bank's ability to perfect liens against a debtor's assets provides it with an incentive to perform its monitoring duties early if the bank waits too long, its liens may be considered a "voidable preference" under $\$ 547$ of the Bankruptcy Code, thereby depriving the bank of any priority status. Here, violations of the APR 
have negative consequences on ex ante efficiency, since they reduce the incentive for bank lenders to monitor early.

Countering these views is a group of papers proposing that APR violations have beneficial ex ante effects. For example, Harris and Raviv (1993) argue that selecting an optimal bankruptcy procedure is an extension of the optimal contracting problem. They analyze several different state-independent bankruptcy procedures and show that they are all dominated by a contract in which a bankruptcy court may impose forgiveness in high-cost-of-liquidation states, suggesting that APR violations are ex ante efficient. Longhofer (1994) looks at how bankruptcy rules affect the incentives for lenders to monitor a firm's behavior and suggests that anticipated ex post APR violations are valuable to the extent that they punish senior lenders (those designated to monitor the firm's behavior) for failing to detect a misbehaving firm. Finally, Bebchuk and Picker (1993) propose that APR violations reduce the incentive of an owner/manager to select inefficient “insider" projects whose values are highly dependent on the manager's personal skills, and encourage the owner/manager to invest in his own human capital. Both of these effects suggest that APR violations are ex ante beneficial.

All of these papers, however, deal with moral hazard problems of one sort or another; whether or not APR violations are beneficial depends on which problem the firm faces at the time of the initial contracting. In what follows, we show that APR violations need have no impact on the firm's ex ante investment decision, either directly by affecting its risk incentives, or indirectly by changing the lender's incentives to monitor the firm. Instead, APR violations make credit rationing more likely: The more the debtor receives in default states, the lower the threshold at which increases in the interest rate reduce the lender's expected return. Furthermore, 
we demonstrate that APR violations also reduce social welfare by making default, which is costly, more likely to occur.

\section{A Model with Debt and APR Violations}

Consider a risk-neutral economic actor living in a two-period world. We may alternatively think of this actor as an individual consumer or as a firm. In the first case, we assume that the individual has some random income in period two, but wishes to consume some good that costs $I$ in the first period; this good might be education, a house, a car, or some other consumer good. In the second case, we can think of the firm as having some project in which it can invest $I$ in the first period to obtain a random return in period two. In either case, the agent dies at the end of period two, and the good/investment chosen in period one has no residual value. In what follows, we will use the "firm" terminology, but it should be clear that either interpretation would work equally well.

Since the firm has no initial endowment, it must raise funds from an outside investor. We will assume a costly state verification environment (Townsend [1979] and Gale and Hellwig [1985]), letting $c$ be the ex post cost of state verification. As a consequence, debt is the optimal financial contract. ${ }^{7}$ Let $\delta$ denote the gross payment (principal and interest) due the investor (henceforth called the lender) in period 2; for ease of exposition, we will ofiten refer to $\delta$ as "the interest rate." In addition, assume that the market of potential lenders is perfectly competitive, that all lenders are risk neutral, and that the riskless rate of interest is one, so that all lenders

${ }^{7}$ Strictly speaking, we are assuming that state verification is perfect and that it occurs in a deterministic manner. If stochastic verification is allowed, the simple debt contract will not, in general, be optimal (see Townsend [1979] and Border and Sobel [1987]). We will discuss the implications of this assumption in section 5 . 
have a reservation return of $I$.

Let $x$ denote the project's return in period two and $\Pi(x)$ be the distribution function for $x$; as is standard, denote the density function by $\pi(x)$, which is strictly positive on its support $[\underline{x}, \bar{x}]$. To make the problem interesting (i.e., to have some risk involved), assume $I>\underline{x}$. Since we are interested in the impact of APR violations, let $\gamma$ denote the payment the borrower receives in default states. Finally, to avoid unlimited liability problems for the investor, assume $\underline{x}>c+\gamma$

The borrower's expected return is then

$$
B(\delta, \gamma)=\int_{\underline{x}}^{\delta} \gamma d \Pi(x)+\int_{\delta}^{\bar{x}}(x-\delta) d \Pi(x)
$$

The lender's expected return is

$$
L(\delta, I, \gamma)=\int_{\underline{x}}^{\delta}(x-c-\gamma) d \Pi(x)+\int_{\delta}^{\bar{x}} \delta d \Pi(x)-I
$$

DEFINITION: A competitive equilibrium in this market is defined by an interest rate $\delta^{*}$ that maximizes the borrower's expected return subject to the constraint that the lender earns zero expected profits,

$$
L\left(\delta^{*}, I, \gamma\right)=0
$$

and subject to the borrower's expected return being non-negative.

Technically speaking, there is always an autarkic equilibrium in which no lending occurs. In this equilibrium, $\delta$ may take any value, since it is never offered to the borrower. 
Equilibrium is characterized by the following proposition:

PROPOSITION 1: In any competitive equilibrium in which lending takes place, the lender's expected return is non-decreasing in the face value of the debt (i.e., $\left.L_{\delta}\left(\delta^{*}, I, \gamma\right) \geq 0\right)$ and the borrower's expected return is non-increasing in the face value of the debt (i.e., $\left.B_{\delta}\left(\delta^{*}, \gamma\right) \leq 0\right)$. Lending will occur in equilibrium only when the cost of state verification, $c$, and the payment to the firm in default, $\gamma$, are sufficiently small.

Proof: Direct differentiation of (1) and (2) verifies that

$$
\frac{\partial B(\delta, \gamma)}{\partial \delta} \leq 0 \quad \text { iff } \quad \frac{1-\Pi(\delta)}{\pi(\delta)} \geq \gamma
$$

and

$$
\frac{\partial L(\delta, I, \gamma)}{\partial \delta} \geq 0 \quad \text { iff } \quad \frac{1-\Pi(\delta)}{\pi(\delta)} \geq \gamma+c
$$

These conditions provide the required upper bound on $c$ and $\gamma$, and imply that $B(\delta, \gamma)$ will be decreasing in $\delta$ whenever $L(\delta, I, \gamma)$ is increasing in $\delta$.

Suppose there exists a $\delta^{*}$ that satisfies the definition of an equilibrium interest rate, but that $L_{\delta}\left(\delta^{*}, I, \gamma\right)<0$. We will show that this cannot occur: Either there exists some $\delta^{\prime} \in\left(\underline{x}, \delta^{*}\right)$ such that $L\left(\delta^{\prime}, I, \gamma\right)=0, B_{\delta}\left(\delta^{\prime}, \gamma\right) \leq 0, L_{\delta}\left(\delta^{\prime}, I, \gamma\right) \geq 0$, and $B\left(\delta^{\prime}, \gamma\right) \geq B\left(\delta^{*}, \gamma\right)$, or there is no lending in equilibrium.

If no $\delta^{\prime}$ such that $L_{\delta}\left(\delta^{\prime}, I, \gamma\right) \geq 0$ and $L\left(\delta^{\prime}, I, \gamma\right)=0$ were to exist, we would have

$$
L(\underline{x}, I, \gamma)=\underline{x}-I>L\left(\delta^{*}, I, \gamma\right)=0,
$$

which is a contradiction, since $I>\underline{x}$; in this case, we have the autarkic equilibrium. If such a $\delta^{\prime}$ does exist, the fact that $B_{\delta}\left(\delta^{\prime}, \gamma\right) \leq 0$ follows immediately from (4) and (5) above. Finally, 
note that

$$
\begin{gathered}
L(\delta, I, \gamma)=\int_{\underline{x}}^{\bar{x}} x d \Pi(x)-B(\delta, \gamma)-c \Pi(\delta)-I=0 \\
\Rightarrow \quad B(\delta, \gamma)=\int_{\underline{x}}^{\bar{x}} x d \Pi(x)-c \Pi(\delta)-I .
\end{gathered}
$$

Thus, $B\left(\delta^{\prime}, \gamma\right)-B\left(\delta^{*}, \gamma\right)=c\left(\Pi\left(\delta^{*}\right)-\Pi\left(\delta^{\prime}\right)\right) \geq 0$, since $\delta^{*} \geq \delta^{\prime}$. Thus, $B\left(\delta^{\prime}, \gamma\right) \geq B\left(\delta^{*}, \gamma\right)$.

This proposition implies that if multiple choices of $\delta$ satisfy $L(\delta, I, \gamma)=0$, then the smallest such $\delta$ will be the equilibrium.

Of course, when a lending equilibrium exists, the APR violations that will occur in default states will be anticipated. As a consequence, the borrower must pay a premium ex ante; i.e., he must pay a higher interest rate. One might imagine that the borrower's expected return in bankruptcy states would exactly cancel his expected added interest costs. This, however, is not the case. To see this, note that the impact of an increase in $\gamma$ on the borrower's expected return is

$$
\Pi(\delta)+\gamma \pi(\delta) \frac{d \delta}{d \gamma}-(1-\Pi(\delta)) \frac{d \delta}{d \gamma}
$$

To calculate the change in the debt payments due to an increase in the APR violation, we totally differentiate (3): 


$$
\frac{d \delta}{d \gamma}=\frac{\Pi(\delta)}{(1-\Pi(\delta))-\pi(\delta)(c+\gamma)}
$$

Finally, we substitute (9) into (8) and simplify to get

$$
\frac{d B(\delta, \gamma)}{d \gamma}=\frac{-c \Pi(\delta) \pi(\delta)}{(1-\Pi(\delta))-\pi(\delta)(\gamma+c)}
$$

The denominator of this expression is the change in the lender's expected return due to an increase in the face value of the debt, and is positive by Proposition 1 . The numerator is clearly negative, showing that the borrower's expected return is decreasing in $\gamma$.

This fact is an immediate consequence of the optimality of simple debt in a costly state verification environment, and its intuition is straightforward. Violations of the APR reduce the lender's expected return from default states. As a consequence, the lender must receive a larger payment in nondefault states, i.e., the face value of the debt must be larger to maintain the zero profit constraint. But a larger face value for the debt means that default will occur more often, which implies its deadweight costs will be incurred more often as well. Notice that if $c$, the deadweight cost of state verification, were zero, then the level of $\gamma$ would have no impact on the borrower's expected return. But, of course, simple debt would no longer be the optimal financial contract if this were the case.

Because ex post state verification is costly, the results of Townsend (1979) and Gale and Hellwig (1985) assure us that debt is, in fact, the best way for the investor to advance funds to the firm. And as a consequence when lending occurs in equilibrium, the existence of APR violations, while beneficial ex post for a borrower in default, actually reduces the borrower's ex ante expected return. The next logical question, then, is how APR violations affect the lender's 
willingness to make loans in equilibrium, i.e., whether they change the likelihood of credit rationing. It is to this question we turn in the next section.

\section{APR Violations and Credit Rationing}

A necessary starting point for our analysis is to define what we mean by "credit rationing." Simply stated, credit rationing occurs whenever excess demand for credit remains in the market in equilibrium. Since the market is in equilibrium, by definition there is no pressure for the interest rate to increase to clear the market, as is the case in the classical Walrasian model. In our model, credit rationing means that no lender is willing to provide the firm's required investment because the interest rate cannot rise enough to ensure that his zero profit constraint (3) is satisfied.

Why can't this occur? The deadweight loss imposed by state verification and the transfer due to the APR violation reduce the lender's expected return in default states. Eventually, increases in the interest rate make default so likely that these costs outweigh the higher return the lender expects to receive in nondefault states. Figure 1 shows $L$ graphed as a function of $\delta$, holding $I$ and $\gamma$ constant. As $\delta$ gets larger, $L$ eventually slopes downward. ${ }^{8}$

Define $\bar{\delta}$ as the interest rate that maximizes the lender's expected return given the

\footnotetext{
${ }^{8}$ Note that $L$ is not necessarily a concave function of $\delta$. All of our results, however, hold true regardless of the shape of $L$.
} 


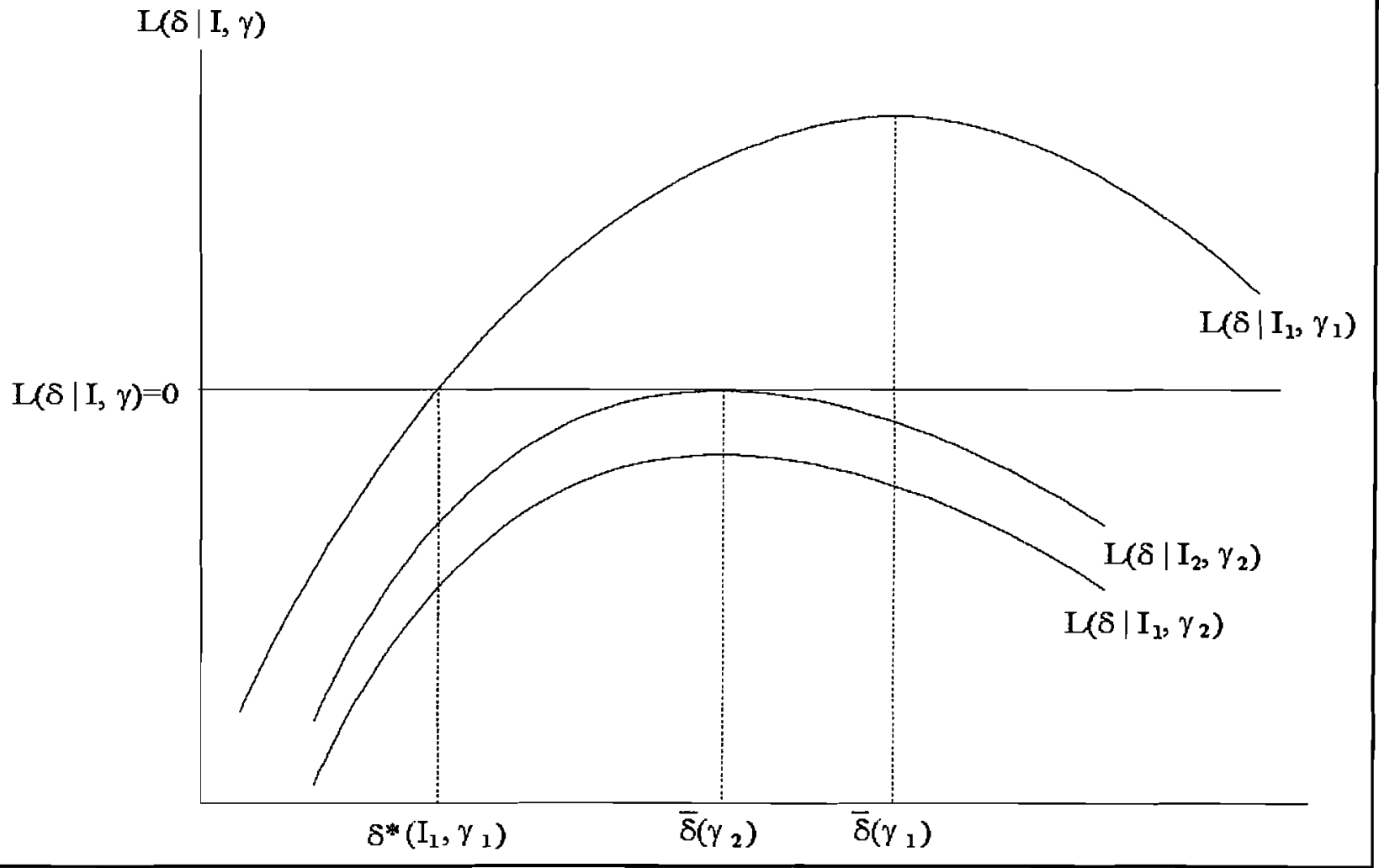

Figure 1

magnitude of the APR violation, $\gamma:{ }^{9}$

$$
\bar{\delta}(\gamma)=\underset{\delta}{\operatorname{argmax}} L(\delta, I, \gamma)
$$

Since increases in $I$ cause $L(\delta, I, \gamma)$ to shift down vertically, we can define $\bar{I}(\gamma)$ as the largest investment that is feasible for the lender to finance: $L(\bar{\delta}, \bar{I}, \gamma)=0$. Totally differentiating this expression with respect to $\bar{I}$ and $\gamma$ gives us

${ }^{9}$ Notice that $\bar{\delta}$ is not a function of $I$, because changes in $I$ are merely vertical shifts of $L(\delta, I, \gamma)$; such shifts do not change the location of the extremum, $\bar{\delta}$, only the value of the function at the extremum. 


$$
\frac{d \bar{I}}{d \gamma}=-\Pi(\bar{\delta})<0
$$

thus proving:

PROPOSITION 2: Larger APR violations increase the magnitude of credit rationing by reducing the size of the largest project that will allow lenders to earn non-negative expected profits.

Figure 1 illustrates the effects summarized in Proposition 2. Holding $I$ constant, an increase in $\gamma$ shifts $L$ down and to the left. ${ }^{10}$ As a result, loans that will be made when the APR violation is $\gamma_{1}$ will not be made when the APR violation is increased to $\gamma_{2}$ - the resulting decrease in the lender's expected return makes loans of $I_{1}$ infeasible. The largest loan a lender is willing to make is, instead, $I_{2}<I_{1}$.

\section{Conclusions}

In this article, we have demonstrated that APR violations can exacerbate credit rationing problems. By lowering the lender's expected return and increasing the cost of default, deviations from the APR make fewer loans profitable for lenders. To the extent that existing bankruptcy law makes APR violations more likely and makes bankruptcy more costly, our results imply that they make credit rationing problems more intense. ${ }^{11}$

\footnotetext{
${ }^{10}$ Technically, this leftward shift depends on the concavity of $L$ with respect to $\delta$. In this case, it is proven by totally differentiating the first-order condition that defines $\bar{\delta}$. Our results, however, depend only on the downward shift, which occurs regardless of whether $L$ is concave in $\delta$.

${ }^{11}$ See Bebchuk and Chang (1992) and Brown (1989) for theoretical models suggesting that the structure of Chapter 11 does, in fact, make APR violations more severe.
} 
This is particularly a problem with respect to loans for individual consumers. As noted before, individual debtors may violate the APR unilaterally by "exempting" some of their assets from the property of the estate. Although the Code allows states to opt out of this provision, individuals may exempt property listed in $\$ 522(\mathrm{~d})$ of the Code, or if their state allows more generous exemptions, they may follow the state's rules instead. Assets that are typically exempt under both state and federal law include an interest in a house, automobile, jewelry, clothing, and other personal possessions; the total value of such assets generally varies from state to state. ${ }^{12}$

This variance in the level of allowed exemptions may provide a means of testing the conclusions reached in this paper. In particular, the results above suggest that consumers in states that allow more generous exemptions would, ceteris paribus, pay higher interest rates and be offered less consumer credit than would borrowers who live in states with smaller exemptions.

This paper has also pointed out that APR violations can be inefficient ex ante even when they have no impact on a borrower's investment incentives. This insight becomes particularly important when one considers consumer applications of the model. In these cases, the typical moral hazard story in which the borrower must choose the distribution of future revenues makes little sense. Since most conclusions about the efficiency or inefficiency of APR violations depend on these moral hazard models, they are most relevant when the borrower is a firm. In contrast, the optimality of the simple debt contract in a costly state verification environment implies that APR violations have negative ex ante consequences for both businesses and individual borrowers.

12 One notable state is Texas, whose homestead law exempts a rural family home of up to two hundred acres regardless of worth. See Weintraub and Resnick (1992), I 4.07. 
Our analysis must be considered with at least one caveat. Boyd and Smith (1993) also note that adherence to the APR can be thought of as nonstochastic monitoring in a costly state verification environment. ${ }^{13}$ In contrast, the optimal contract when stochastic monitoring is allowed typically involves some element of debt forgiveness - i.e., a violation of the APR, similar to that proposed by Harris and Raviv (1993). Since we have selected a costly state verification framework for our model, at least one of the theoretical benefits of APR violations is present. A more comprehensive model would measure the relative costs we develop here with the benefits of stochastic state verification to evaluate the true impact of APR violations. Our primary conclusions about APR violations and credit rationing, however, are unaffected by this issue.

${ }^{13}$ Boyd and Smith point out that the APR and nonstochastic monitoring are not strictly synonymous. Rather, they "associate an absolute priority rule with nonstochastic monitoring because - if stochastic monitoring were easy to implement - there would be no reason to have an interest in absolute priority rules in this environment" (Boyd and Smith [1993], footnote 4). 


\section{REFERENCES}

Aghion, Philippe, Oliver Hart, and John Moore. "The Economics of Bankruptcy Reform." Journal of Law, Economics, and Organization, 1992, 8(3), 523-546.

Bebchuk, Lucian A. "A New Approach to Corporate Reorganizations." Harvard Law Review, 1988, 101(4), 775-804.

Bebchuk, Lucian A. "The Effects of Chapter 11 and Debt Renegotiation on Ex Ante Corporate Decisions." Harvard Law School, Program in Law and Economics Working Paper 104, December 1991.

Bebchuk, Lucian A. and Howard F. Chang. "Bargaining and the Division of Value in Corporate Reorganization." Journal of Law, Economics, and Organization, 1992, 8(2), 253-279.

Bebchuk, Lucian A. and Randal C. Picker. "Bankruptcy Rules, Managerial Entrenchment, and Firm-Specific Human Capital." University of Chicago, Working Paper in Law and Economics No. 16, 1993.

Berkovitch, Elazar and Ronen Israel. "The Bankruptcy Decision and Debt Contract Renegotiations." University of Michigan, unpublished manuscript, 1991.

Betker, Brian L. "Management's Incentives, Equity's Bargaining Power, and Deviations from Absolute Priority in Chapter 11 Bankruptcies." Journal of Business, April 1995, 68(2), 161-183.

Border, Kim and Jon Sobel. "Samurai Accountant: A Theory of Auditing and Plunder." Review of Economic Studies, 1987, 54, 525-540.

Boyd, John H. and Bruce D. Smith. "The Welfare Costs of Absolute Priority Rules: Stochastic Versus Nonstochastic Monitoring in a Costly State Verification Environment." Federal Reserve Bank of Minneapolis, Working Paper No. 512, May 1993.

Brown, David T. "Claimholder Incentive Conflicts in Reorganization: The Role of Bankruptcy Law." Review of Financial Studies, 1989, 2, 109-123.

Bulow, Jeremy I. and John B. Shoven. "The Bankruptcy Decision." Bell Journal of Economics, $1978,9,437-456$.

Calomiris, Charles W. and R. Glenn Hubbard. "Firm Heterogeneity, Internal Finance, and 'Credit Rationing.'” Economic Journal, March 1990, 100(399), 90-104. 
Eberhart, Allan C., W.T. Moore, and R.L. Roenfeldt. "Security Pricing and Deviations from the Absolute Priority Rule in Bankruptcy Proceedings." Journal of Finance, December 1990, 45(5), 1457-1469.

Eberhart, Allan C. and Lemma W. Senbet. "Absolute Priority Rule Violations and Risk Incentives for Financially Distressed Firms." Financial Management, Autumn 1993, 22(3), 101-116.

Eberhart, Allan C. and Richard J. Sweeney. "Noise: The Case of the Market for Bankrupt Firms' Securities." Stern School of Business, Working Paper S-93-51, 1994.

Franks, Julian R. and Walter N. Torous. "How Firms Fare in Workouts and Chapter 11 Reorganizations." University of California-Los Angeles, Working Paper No. 1-91, September 1991.

Franks, Julian R. and Walter N. Torous. "A Comparison of Financial Recontracting in Distressed Exchanges and Chapter 11 Reorganization." Journal of Financial Economics, 1994, 35, 349-370.

Gale, Douglas and Martin Hellwig. "Incentive-Compatible Debt Contracts: The One-Period Problem." Review of Economic Studies, 1985, 52, 647-663.

Gale, William G. "Federal Lending and the Market for Credit." Journal of Public Economics, 1990, 42, 177-193.

Gertner, Robert and David Scharfstein. "A Theory of Workouts and the Effects of Reorganization Law." Journal of Finance, September 1991, 46(4), 1189-1222.

Harris, Milton and Artur Raviv. "The Design of Bankruptcy Procedures." Northwestern University, Kellogg Graduate School of Management, Working Paper No. 137, March 1993.

Longhofer, Stanley D. "Bankruptcy Rules and Debt Contracting: On the Relative Efficiency of Absolute Priority, Proportionate Priority, and First-Come, First-Served Rules." Federal Reserve Bank of Cleveland, Working Paper No. 9415, November 1994.

LoPucki, Lynn M. and William C. Whitford. "Bargaining over Equity's Share in the Bankruptcy Reorganization of Large, Publicly Held Companies." University of Pennsylvania Law Review, 1990, 139, 125-196.

Rajan, Raghuram and Andrew Winton. "Covenants and Collateral as Incentives to Monitor." Northwestern University, Working Paper No. 184, July 1994. 
Roe, Mark J. "Bankruptcy and Debt: A New Model for Corporate Reorganization." Columbia Law Review, 1983, 83, 527-602.

Stiglitz, Joseph E. and Andrew Weiss. "Credit Rationing in Markets with Imperfect Information." American Economic Review, June 1981, 71(3), 393-410.

Townsend, Robert M. "Optimal Contracts and Competitive Markets with Costly State Verification." Journal of Economic Theory, 1979, 21, 265-293.

Weintraub, Benjamin and Alan N. Resnick. Bankruptcy Law Manual, 3d ed. Boston: Warren, Gorham \& Lamont, 1992.

White, Michelle J. "Public Policy toward Bankruptcy: Me-First and Other Priority Rules." Bell Journal of Economics, 1980, 11, 550-564.

White, Michelle J. "Bankruptcy Costs and the New Bankruptcy Code." Journal of Finance, 1983, 38, 477-504.

Williamson, Stephen D. "Costly Monitoring, Financial Intermediation, and Equilibrium Credit Rationing." Journal of Monetary Economics, 1986, 18, 159-179.

Williamson, Stephen D. "Costly Monitoring, Loan Contracts, and Equilibrium Credit Rationing." Quarterly Journal of Economics, 1987, 102, 135-146. 